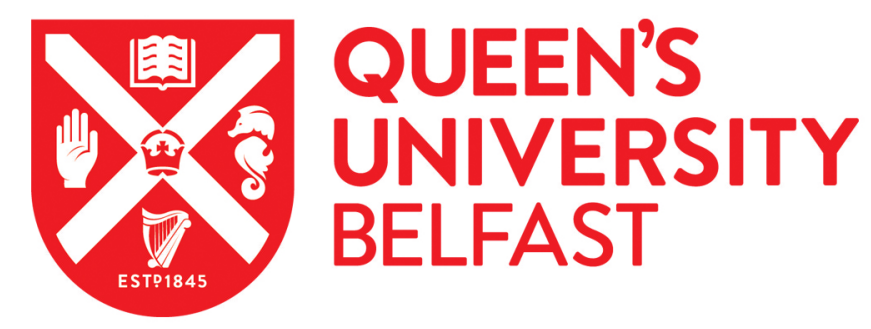

\title{
Chasing the Green Buck? Environmental Activism in Post-communist Baltic States
}

Agarin, T., \& Grivinš, M. (2016). Chasing the Green Buck? Environmental Activism in Post-communist Baltic States. Communist and Post-Communist Studies, 49(3), 243-254.

https://doi.org/10.1016/j.postcomstud.2016.06.001

\section{Published in:}

Communist and Post-Communist Studies

\section{Document Version:}

Peer reviewed version

Queen's University Belfast - Research Portal:

Link to publication record in Queen's University Belfast Research Portal

\author{
Publisher rights \\ (C) 2016 Elsevier \\ This is an open access article published under a Creative Commons Attribution-NonCommercial-NoDerivs License \\ (https://creativecommons.org/licenses/by-nc-nd/4.0/), which permits distribution and reproduction for non-commercial purposes, provided the \\ author and source are cited.
}

\section{General rights}

Copyright for the publications made accessible via the Queen's University Belfast Research Portal is retained by the author(s) and / or other copyright owners and it is a condition of accessing these publications that users recognise and abide by the legal requirements associated with these rights.

Take down policy

The Research Portal is Queen's institutional repository that provides access to Queen's research output. Every effort has been made to ensure that content in the Research Portal does not infringe any person's rights, or applicable UK laws. If you discover content in the Research Portal that you believe breaches copyright or violates any law, please contact openaccess@qub.ac.uk. 


\section{Chasing the Green Buck? Environmental Activism in Postcommunist Baltic States}

Timofey Agarin (Queen’s University Belfast) \& Miķelis Grīviņš (Baltic Studies Centre, Latvia)

The paper investigates the dynamics evolution of issues on the agenda of Baltic environmental non-governmental organisations' since the collapse of communism. The past research on Baltic environment activism suggests that these enjoy high visibility because they tapped the core societal views of natural environment as a crucial asset of a nation. As we demonstrate in this paper, the changes in agendas of Baltic ENGOs make clear that since Baltic groups tapped interchangeably the rhetorical toolbox of 'national environment' to mainly achieve greater financial gains for individual members, rather than for society at large. We illustrate how the dearth of economic opportunities for domestic publics has impacted perceptions of 'nature' advocated by the environmental activists, focusing specifically on national perceptions of ownership and the resulting actions appropriating 'nature' as a source for economic development, only tangentially attaining environmental outcomes on the way. The vision that the 'environment' is an economic resource allowed ENGO activists to cooperate with the domestic policymaking while tapping international networks and donors for funding. Throughout the past decades they worked to secure their own and their members' particularistic economic interests and, as we demonstrate, remained disengaged from the political process and failed to develop broader reproach with publics.

Keywords: environmental activism, economic development, NGOs, Baltic States

\section{Introduction}

Over the past decades, civil society has become one of the focal points for studies of interest based activity, operating locally but following a broader societal agenda. Most analyses reference civil society as a realm, where individuals interact outside the dominant social, economic and political structural constraints (Linz and Stepan, 1996; Reisinger et al., 1995). Unfettered from state control and freed from established institutional pressures, civil society is generally perceived to be the forum where citizens negotiate common agendas and join in collective action (Chandhoke, 2001). As such, participation in civil society groups performs two interrelated yet distinct functions. First, civil society groups feature as a clearing house for individual grievances and concerns which cut across social groups. The proponents of the view hold that civil society helps prioritise competing societal interests, allows overcoming of the collective action problem and supports policymakers' dialogue with society affected (Almond and Verba, 1963). Another perspective on civil society suggests that such groups amortise the failings and deficiencies of policies, indicating to political leadership which reform opportunities are likely to garner public support (Meyer, 2004). Civil society initiatives allow policymakers to identify issues and grievances overlooked by the entrenched bureaucratic elites and incumbent politicians, allow state to draw citizen views into policymaking process and improve policy effectiveness. Despite their difference regarding 
the focus of activity, creating bonds between citizens in the first instance and between state institutions and society in the second, both functions of civil society are widely acknowledged to diversify social interactions, improve civic culture, make political decisionmaking more accountable to populations they serve and allow citizens to shape policy priorities.

Yet, the real-life incarnations of civil society, the non-governmental organisations (NGOs) are set in the environment of concrete political institutions and reflect on the existing policy agendas. NGOs link political elites with the wider society, when they articulate interests which the agencies of the state cannot identify or are unable to address adequately (Diamond et al., 1997). The NGOs evaluate policies, provide general public with access to information and engage with domestic and international policymakers and thus, are not always antagonising politicians. Indeed, political leaders have sought to engage NGOs in public-private partnerships on issues where the state's institutional capacity is low and where necessary decisions might be unpopular with the affected publics (Zakaria, 2013). As a result, citizen groups increasingly profile themselves as policymakers' advisors, while policymakers treat NGOs as partners in implementation and monitoring of policies where existing institutions lack expertise and experience.

The capacity of NGOs to engage with policymakers effectively however, was significantly undermined by the mode of political and economic transition in the postcommunist region. The radical deregulation and neoliberal discourse both positioned as the only viable routes towards full membership in the European community of states and societies (Wallace et al., 2012). These alternatives to the socialist centralism emphasised the retreat of the state from societal organisations, marginalised representation of interests that did not have clearly identifiable economic outcomes, and constrained civil society activism in the highly deregulated societal, political and increasingly so, economic contexts. For example, pre-accession funding for civil society initiatives was made subject to increasing international partnerships whereby national and sub-national governments were encouraged to cooperate with the NGOs in pursuit of development goals domestically (Grosse, 2010; Orr, 2008). The introduction of institutions that grant civil society organisations access to policymaking, enhance public debate in a forum where grassroots initiatives could be articulated has rarely used to pursue collective actions in the manner that extolled challenges to the political decision making. Instead, 'the hybrids of democratisation and "institutional façade" and the mixture of marketization and clientelism [...] perpetuated unfavourable settings of socialism for unions and has added new constraints' (Kutter and Trappmann, 2010, p. 47).

Scholarship on postcommunist civil society groups has long suggested that the EU membership conferred specific rights and responsibilities on civil society actors, but their enforcement was feasible only for short time after the EU accession (Fagan, 2005). The EU accession of several postcommunist states of Central Eastern Europe (CEE) allowed scholars to analyse developments in the civil society sector there through the lens of enlargement conditionality process (For example, Parau, 2009). Some past work has disaggregated the effects of EU's explicit enforcement instruments from the impact of more implicit mechanisms of the enlargement conditionality making clear that those civil society groups that work on the respective policy realm gained initial capacity to draw on the support of 
central policy actors, while the rest were pushed into obscurity (Pieper, 2006). As a result, the local grassroot NGOs have rarely benefitted from the EU capacity building programmes, while many NGOs developed into capital-based, elite-led organisations of service providers working on financial inputs from the international donors. In sum, while both types of nonstate actors have gained sufficient autonomous action capacity to co-operate with the state, they were still ill-equipped to advance societal demands and hold state actors accountable for policies implemented.

The stable flow of external funding meant that postcommunist NGOs could participate in transnational networks and European umbrella organisations to learn how to shape and implement EU policies, both at the EU and the domestic level (Obradovic and Pleines, 2007; Pleines, 2011). And though, the NGOs launched campaigns against national governments, raised national profile and gained international recognition, all their actions were predicated upon availability of the external resources (Agarin, 2011; Orr, 2011). This dependence on resources of both the states and the NGOs during and after the accession meant that civil society groups played a role in policymaking only when they attached a check to their advice (See, Henderson, 2002). Thus, despite these ample opportunities offered by the EU enlargement to strengthen capacity of civil society, the NGOs from accession states have rarely become systematically empowered. Instead, civil society groups needed to repeatedly carve out the new niche for engagement with both the state policies which were largely prescriptive, and society, which was preoccupied largely with more immediate economic concerns.

Many analysis point out that the domestic political factors impacted the NGO activities and over time relegated civil society actors to the role of auxiliary governmental advisors; while other scholars indicate that the European monitoring of the member-states gradually strengthened the autonomy of central government and allowed these to outmanoeuvre civil society groups more critical of the overall direction of policy development. Our paper overviews these debates and suggests that while many civil society groups are involved in and claim responsibility on particularistic agendas, the long-terms outcomes of their engagement feed into broader - and as yet, unanticipated - outcomes. We focus specifically on the case of environmental groups in the Baltic States. We observe that the NGOs that started off with concerns over nature, have edged towards broader issues of participation in policymaking, whilst those that have established themselves as pioneers of the 'green cause' have originally worked on a rather different agenda. This paper builds on the prior research on ENGOs which claimed that environmental groups reflect the close connection between the narratives about the 'nature' as a part and parcel of 'national resource'. The following discussion qualifies these past findings and argues that the citizens active in the protection of environment, primarily targeted financial inputs for their own and their groups' - economic welfare.

The dynamic agendas of civil society groups have been analysed extensively, with the past research focussing on both the NGOs ability to assist in governance tasks, as well as with their capacity to pursue self-set goals. In our paper we combine these findings to explore how civil society activism empowers the members of society to partner up with the international NGO community, their state, and each other to shape the direction of policy development and change political agendas. The following analysis consists of three sections. 
At first, the paper turns to analyses of the relationship between Baltic environmental groups and nation-building practices in the post-Soviet Estonia, Latvia and Lithuania. It then examines the agendas regarding environmental protection and sustainability by analysing processes of ENGO professionalization, alignment with economic rationale and adoption as well as adaption of the narrative of environmental development. The paper concludes with a case study of environmental groups in Latvia which had developed some ecological expertise but have continuously reframed, and as such, perpetuated economic rationale in their work.

\section{The nature as an agent of development in Baltic environmental activism}

The extant research on NGOs in the postcommunist EU member-states analysed them as primarily reflecting domestic perceptions of policy expectations in the context of the EU enlargement, and later membership. Since beginning of the EU accession negotiations and up until the economic crisis of 2008, streams of European funding were intended to strengthen the capacities of civil society. Yet the research on the NGOs in the 'new' member-states suggests that they have tapped into structural opportunities to push their agendas forward domestically rather than team-up with domestic and international partners on long term projects (Kutter and Trappmann, 2010; Sudbery, 2010). The protruded demand for policyexpertise improved government performance, but at the same time compromised the NGO capacity to campaign and neglected entirely their legitimacy as watchdogs of decisionmakers (Trenz and Eder, 2004).

Within this wider framework, the contribution of environmental groups to policy implementation has been analysed extensively (Crotty, 2006; Rootes, 2002), yet mostly in terms of self-declared goals. Previous scholarship focused on ENGOs narratives about the environment and practices of nature protection (Carmin and Vandeveer, 2004), their impact on communities affected (Fagan and Sircar, 2011) and groups' management of available financial resources (McCauley, 2007). Like in other socialist states and republics of Central Eastern Europe in the late 1980s, Baltic environmental movements rallied on democratic platforms and are believed to have brought political liberalisation and state independence (Baker and Jehlicka, 1998). Similar to opposition to nuclear power development in Czechoslovakia, the building of a hydroelectric plant on the Danube in Hungary, and the expansion of chemical production in Armenia, environmental activism in the Baltics referenced 'nature' in order to enhance the potential of the 'nation'. The core aim of this entrepreneurship focused on the framing of nature as a living environment for the people who owned the state, while simultaneously promoting economic liberalisation.

The literature dealing directly with environmental action in postcommunism in general and in the Baltic States in particular points out that environmentalism acquired force in response to new structural opportunities (Dawson, 1996; Gille, 2000). When communism collapsed, Western practitioners concerned with the European environment gained first hand contact with postcommunist environmental activists. These observers concluded that Eastern Europeans perceived the human role in interaction with the ecosystem as being limited to environmental protection, rather than environmental sustainability (Hicks, 2004). Others, however, suggested that environment was seen as a resource for human use, supporting previous research on its poor ecological state after the collapse of socialism (Mirovitskaya, 
1998; Tickle and Welsh, 1998). Many asserted that post-communist publics were unlikely to engage in Western-style environmental activism, since they had much more pressing issues on their agenda than environmental problems (Lee and Norris, 2000; Waller and Millard, 1992).

Over the last decades of communism, citizens have been pushing states to develop environmental policies and have linked environmental conditions during the socialism with the grievances of a nation affected by poor ecological situation laid claims to ownership over the nature as a resource for human use (Kramer, 1983). Katrina Schwartz (2006) concurs, arguing that in the late 1980s Latvia's 'green' activism was salient thanks to the close connection between the landscape and national identity in Latvians' imagery of their homeland, ushering independence movement. Similarly, Matthew Auer holds that Estonians' environmental concerns featured in the broader context of opposition to Soviet wasteful exploitation of the nation's natural resources (1998). While the Soviet regime conceived industrial development as a means to affect social change, ecological movements spurred in opposition to both social and ideological developments under communism (Ziegler, 1992). The consensus prevails that the nature was a place holder for another issue at the centre of the Baltic national movements, for sovereignty over the national environment (Muiznieks, 1995).

To a degree, these different views of the environment could be traced back to closeknit relationships between Baltic, as well as many Eastern European nations' with their natural surroundings. In the case of Latvia to which we return later in the paper, two competing ideological interpretations of nation's place in the natural environment have developed into and penetrated popular understanding of cultivation of land since the end of the 19 century. Here, 'living from the nature' is contrasted with the nation's embeddedness in the environment, often referred to as 'living with the nature' (Bērziňš, 2000; Grīnberga, 1999). These views are reiterated by members of the environmental groups throughout the region to emphasise their nations' close ties with their natural environments (Pavasars, 2014). Additionally, Sikk and Andersen (2009) and Agarin (2009) have shown that the natural environment of the Baltic peoples was actually a national environment, allowing elites to gain political capital out of ecological concerns. Thus during the 1980s, the environmental groups cooperated in order to push for greater national sovereignty, allowing most members of the environmental protection groups to become part of the early governmental coalitions after independence from the USSR (Galbreath, 2009).

Since post-communist publics had reinstated sovereignty, many observers of environmental action asserted that despite the vocal rhetorical commitment to environment, views and behaviours similar to those observed in the Western Europe as regards environmental equity were nowhere to be seen across the region (Gooch, 1995; Slocock, 1996). Yet regardless, following independence from the USSR the most vocal representatives of the ENGOs have been catapulted into office on the green platform and were 'capitalising on the aspirations of economic growth and dismissing environmental activists as partners in policymaking process.' ${ }^{1}$ While political elites and societies alike came to perceive environmental groups as a source of disturbance, they pointed out that the 'greens' were

1 Interview, Lithuanian Green Movement (Vilnius, August 2009). 
holding views irreconcilable with the new 'environmental' agenda. ${ }^{2}$ This forced Baltic environmental activists to shift the focus of their activities from environmental restoration to concerns over economic development. Yet, the perception of human stewardship over nature remained central to ENGO activists' engagement with economically sustainable governance. When land ownership was restored to pre-Soviet owners after the collapse of Soviet Union, the view of 'living with the nature' made inroads into the environmental movement and has been instrumentalised by postcommunist civil society groups (Grivins and Tisenkopfs, 2015). Modernization, concentration of land and the introduction of industrial cultivation of land were reframed as the major opportunity that would allow the national economy to compete in the global arena (Locmele, 2014; Šūmane, 2010).

In the early 1990s, Baltic environmental activists have accessed European environmental protection scene, witnessing an established consensus on global environmental sustainability, including the link between ecology and economy as the driving force for environmental protection. The commitment to a rationale of sustainable development was embedded in Treaties of the EU, allowing observers to conclude that sustainable development became a norm of EU politics (Baker and Welsh, 2000). Downloading Western European rhetoric of sustainable development made Baltic environmental activists 'reconciliatory towards economic liberalisation when national policymakers welcomed [ENGOs] help in absorbing investment into national budgets'. ${ }^{3}$ Baltic governments took little opportunity to miss financial input from Western European environmental groups and promptly implemented strategies to assess the region's biodiversity and sustainability when funds were made available for the purpose (Lazdinis et al., 2004).

Although environmental groups in each of the Baltic States cooperated on the ground, they muddled through two problematic legacies of past environmental activism. On the one side of the environmental spectrum, there stood groups focused on the areas where the natural environment and biodiversity remained relatively untouched by industrialisation. Earlier research also confirms that the discourse of 'agrarian nationalism' prevailed in these groups, who largely (although not exclusively) appealed to local visions of nationhood (Katrina Z. S. Schwartz, 2006). The groups such as the Environmental Protection League in Estonia and the Latvian Nature Fund consistently focused on the conservation of pristine environments, instead of improving the environmental conditions in the regions worse affected (LVA, 1996; Tesnova, 1995). In this context, 'advocacy of nature conservation, recommendations on withdrawal of land from agricultural use and protection of the remaining unspoiled land' were central to these groups' activity. ${ }^{4}$ These suggestions faced fierce opposition from the local communities, desperately needing financial revenues. Particularly the proprietors of the restituted land and the owners of forests preferred harvesting, rather than protecting nature. ${ }^{5}$ Those who preferred cultural landscapes preserved in the forms of national parks and industry-free zones found international NGOs (INGOs) language fitting well with popular

\footnotetext{
2 Interview, Estonian Green Party (Tartu, March 2009).

3 Interview, Environmental Protection Club of Latvia (Riga, August 2009).

4 Interview, Lithuanian Green Movement (Vilnius, August 2009).

5 Interview, Environmental Information Centre (Vilnius, August 2009).
} 
ideas about liberation from industrial development and human interference with national nature.

On the other side, groups pushing for sustainable ecological management were combating pollution by large Soviet-era enterprises by requesting investment into both the infrastructure in the worst offending industries (Gorton et al., 2005). In a sense, this is what most of the Baltic ENGO activists were aspiring to but were unable to do during the 1980s. ${ }^{6}$ Many made use of the available funding from international donors for a range of activities. During the 1990s, the INGOs, notably the World Wildlife Fund (WWF), Friends of the Earth and Baltic Environmental Forum (BEF) exposed local environmental groups to Western European concepts of sustainable development and ecological use of resources. These INGOs helped Baltic ENGOs link the global narrative of sustainability with the prevailing understanding of environments as resource of a nation. The Tallinn Office of the Stockholm Environmental Institute was particularly vocal in supporting the westward re-orientation of Estonia's ENGOs ${ }^{7}$, while in Latvia cooperation between the environmental groups with WWF and BEF has aided local groups to plug into the European discourse on environmental protection. In Lithuania, cooperation was enhanced by financial incentives for the ENGOs to engage with administrations of municipalities, which additionally provided governmental officials insights on dealing with the NGO expertise. ${ }^{8}$ Premised on the belief that economic development should not lead to ever-increasing state intervention, Western views of the environment heavily resonated with many individuals involved in the late Soviet ecological movements, many of whom now occupied governmental posts. Financial support injected through the INGOs was crucial for setting up plans and processes, upgrading equipment, establishing competent authorities and reporting on law enforcement. Granted financial support, such organisations as Estonian Nature Society (Eesti Loodus Selts) and Latvia's Environmental Protection Club (Vides aizsardzības klubs) addressed economic difficulties of both rural and urban residents affected by the technocratic exploitation of the environment during and after the collapse of the Soviet Union (Kaasik et al., 1995).

Perceivably, cooperation with Western partner organisations allowed the Baltic ENGOs to sustain some basis to monitor governmental performance and assessing ecological issues. Across Latvia's industrial areas and across Estonia's Northeast, environmental groups mushroomed to facilitate capacity-building in the industrial sector as a means of reducing air pollution, while at the same time addressing the consequences of industrial close down for national economies. All the same, by mid-2000s ENGOs received essential resources to address environmental problems in the ecological hotspots and gained the know-how for monitoring the implementation of international agreements and obligations. Not only rural communities, but also areas of dense industrial development, that were previously distinguished by growing poverty, boasted a range of local ENGOs working off international grants. Particularly in Estonia, many small ENGOs emerged to address local environmental concerns of small communities, including regional groups such as Estonian Seminatural Community Conservation Association and the Nõmme Road Society. In Latvia ENGOs were

\footnotetext{
6 Interview, World Nature Fund (Riga, August 2009).

7 Interview, Estonian Society for Nature Protection (Tallinn, July 2009).

8 Interview, Environmental Centre for Administration and Technology (Vilnius, August 2009).
} 
locally focused, but also concentrated on specific challenges of industrial developments leading to the emergence of such groups as Latvia's Marine Association (Latvijas Jurniecibas savieniba), Electroenergy and Energy-building Association (Latvijas Elektroenergetiku un elektrobuvnieku asociacija), and Waste Management Association (Latvijas Atkritimu saimniecibas asociacija). Bolstering international support networks, conservationists such as Estonian Ornithological Society and Lithuanian Ecological Agriculture Association 'Gaja' advocated the complete closure of the Soviet industrial parks. Other ENGOs, such as Lithuanian Friends of the Earth 'Atgaja' and Latvia's Green Freedom suggested reform of the industrial sector to improve the existing environmental conditions. ${ }^{9}$ Conservationists were most effective in Lithuania, where they considerably facilitated governmental negotiations around the closing of the Ignalina nuclear power plant. In Latvia, Latvia's Green Movement aligned with a pre-Soviet notion of 'Latvianness' idealised by a traditional homestead and life from the land, and were increasingly engaged in supporting the development of the national parks and nature reserves (Locmele, 2014). Similarly, extensive cooperation with the state authorities, consultations on creating nature parks across the country and establishing smaller nature reserves in Western Estonia's boggy landscape were typical for the Estonian groups, such as Baltic Green Belt (Läänerannik) and many others (Ehrlich et al., 2002). In so doing, many local ENGOs decisively shaped policy developments to manage natural resources, protect landscapes and support sustainable use of the environment to preserve it as a cradle of national culture (Toomik and Liblik, 1998).

Although the Baltic ENGOs continued to speak of the natural environment as a part of the national heritage, they increasingly came to operationalize their activities as an asset for economic development. By the time of the EU accession, many environmental activists had accessed international funds and cooperated with Western INGOs coming full circle, intricately connecting resources of environment with the national prosperity. Some groups focused on environmental protection, advocating the creation of national parks and protected areas, while others sought to limit the use of natural resources for the projects that enhanced socio-economic value of environment. Yet at all times, the focus was placed squarely on more tangible policy outcomes, not necessarily envisaged by policy makers, or anticipated by the ENGOs themselves. All ENGOs sought to access economic resources by emphasising the symbolism of nature in order to attract funding and legitimise their work to domestic publics.

\section{Environment as an economic resource}

The EU-accession galvanized Baltic public interest in ecological problems and revitalised environmental activism in the region. Like all countries acceding to the EU, the Baltic States had to adapt the acquis communautaire, the EU legislative corpus. Yet with the EU membership, environmental policies were handled down to postcommunist member-states (Caddy, 2000; Gorton et al., 2005), and while the governments were encouraged to engage with environmental problems (Eckerberg, 1997), cooperate on regulation issues (Kratovits, 2001) and coordinate national policies (Jacoby, 1999; Vogler, 1999). Much of this was 
possible thanks to the incentives from Western development funds, international agencies and international NGOs keen on guaranteeing a greener future for postcommunist societies (Rootes, 2002). This 'asymmetric dependency' of the accession countries on the EU had forced national ENGOs to make economic transition ecologically efficient (Pavlínek and Pickles, 2005). Yet since the accession, external funding for postcommunist NGOs was cut considerably as a result of both the EU-accession, effects of the economic crisis and shifting policy priorities. These cuts challenged the ability of many ENGOs to pursue the activities they prioritised in the past.

The considerable change in priorities of local ENGOs during the enlargement phase reflected the financial and technical assistance these received from the INGOs, international organisations and donor states. Transfers of environmental expertise from Western policymakers and ENGOs helped to make sense primarily of economic opportunities, arriving with international grants for environmental protection and redevelopment. Everywhere across Central and Eastern Europe, the 'vertical disintegration of policy' on the environment and the necessary reporting on the fund allocations granted through international development agencies helped ENGOs translate general commitments into measurable acts and tasks (Bomberg, 2007). To bridge the gap between donor prescriptions and interests of local communities, ENGOs had to continue with environmental protection and raise businesses' awareness for cleaner technologies.

As ENGOs were framing environment as a national resource, the financial shortages drew their agendas closer to those of governments. Cooperation with the INGOs helped national ENGOs to stay focused on policy-expertise to support economic growth and to monitor their countries' commitments to the developmental agenda. Inevitably, most of ENGOs sought participation in activities along those spelt out in environmental policies, prompting more intensive communication with their national governments and cooperating on a range of issues, where cooperation seemed impossible earlier.

On the way, the Baltic environmental groups moulded national narratives with the managerial approach to environment. This made ENGOs look for local projects which fitted foreign narratives and brought economic advantages to maintain activities in the affected communities. Where ENGOs transferred some financial support to the regions suffering from chronic underemployment and effects of industrialisation, they were welcomed. In areas where local communities could not implement environmentally friendly practices, the scarcity of the available external funding was blamed for the lack of effect on local communities. $^{10}$ External logistic support from Western INGOs allowed additional cooperation between the environmental activists, local authorities and national governments on ecological issues that could secure revenues for the affected communities. Only the ENGOs receiving Western financial support could balance the economic profitability argument with those aimed at aesthetic appeal of the natural environment.

To this end, many local environmental activists created programmes for sustainable resource management, as requested by European donor organizations. A range of ecological projects, some dating back to the late 1980s, which 'previously sought to allow a natural

10 Interview, Estonian Wildlife Fund (Tartu, July 2009). 
regeneration of environment' were 'redrawn to secure financial support from the West'. ${ }^{11}$ Adopting the discourse of ecological modernization allowed many ENGOs to capitalise of their previous experiences, continue cooperation with authorities and importantly, engage with industrial enterprises, perceived by the governments as key actors in economic transformation (Mzavanadze, 2009).

The Estonian Wildlife Fund (Eestimaa Looduse Fond, EWF) was raising public awareness about environmental issues since 1991. In the changing political environment, the EWF had been largely receptive to funding remaining available after Estonia's EU-accession. Whilst previously the EWF was monitoring and participating in establishing protected areas, the Soomaa and Karula national parks and Alam-Pedja Nature Reserve, as well as inventorying wetland and forest habitats, since 2004 it engaged in environmental education and raising public awareness of environmental activities. A similar organisation in Latvia, World Wildlife Fund - Latvia (Pasaules Dabas Fonds, WWF Latvia) was founded in 1991 as an environmental conservation organisation and has been working as a local representative of the WWF to improve sustainable use of the environment during Latvia's transition (Busmanis, 1991). By engaging in various nature conservation projects since 2004, WWF Latvia was persistent in seeking to restore natural landscapes by developing pressure lands on abandoned arable sites, supporting sustainable forestry. Similarly, the Baltic Environmental Forum (BEF) founded in 1995 was active in the areas of nature conservation, water and air pollution and waste management but also engaged supported transposition of the EU environmental legislation and monitored implementation. However, following EU enlargement, the BEF has become involved with environmental education related to consumer behaviour, issues of trans-boundary cooperation in ground-water protection, especially in relation to the agricultural use of chemicals. Lithuanian partners suggest that 'international grants allowed groups under the umbrella of the BEF to provide training in environmental issues to industrial entrepreneurs, while officially delivering analyses to state and local authorities on water and air pollution, chemicals and consumer attitudes. ${ }^{12}$

While the BEF represents an example of ENGO cooperation at local and regional levels, cooperation between ENGOs involving a state is only seen in Estonia. The Estonian Council of Environmental Organizations (ECEO) was established in early 2001. The first joint funding for ECEO's activities was acquired in 2004 from the Baltic-American Partnership Program. Following this initial cooperation, it was not until 2006 that the Estonian State allocated around 35,000 EUR of core funding for environmental activities to support ENGOs. On this basis, the Council not only employed a coordinator, but was also able to provide bottom-line funding for consolidation of its member ENGOs and engaged in representing environmental issues in the public, regularly receiving media coverage. Curiously, 'Cooperation is good [between Estonia's ENGOs], although different groups apply for the same money and speak to different audiences through competing media. We think that the influence of different groups on political decisions depends on individual and NGO track record of attracting international funding. ${ }^{13}$

11 Interview, Estonian Society for Conservation of Nature (Tartu, April 2009).

12 Interview, Environmental Centre for Administration and Technology (Kaunas, August 2009)

13 Interview, Estonian Green Movement (Tartu, July 2009). 
In Lithuania, where no financial support is streamlined from the state, ENGO cooperation was dampened by their competition for international project related funds. Such competition undoubtedly impeded an earlier formation of the Coalition of Lithuanian Environmental Organizations. When established in 2005, the Coalition was primarily meant to act on the funds provided by Norwegian ecological development grants, which was combined with access to the EU Small Grants. However, despite representing 'environmental stake holders from across the country, the Coalition does not communicate well with the Ministry of Environmental Protection. It seems that there are effects only when individual ENGOs have time left to monitor situation in Visaginas [the location of a nuclear power plant], support agri-environmental planning and screen biodiversity'. ${ }^{14}$ Unlike the Estonian and Lithuanian ENGO councils, cooperation among Latvia's ENGOs was supported by the state with the organisation of the Latvian Environmental Advisory Council in 2003 under the aegis of the Ministry of Environment. While initially the council was designed to facilitate the exchange of information between the 20 ENGOs representatives and an official from the Ministry of Environment, currently it functions as 'a major tool of delegating state responsibility for environmental issues so that public actors can deal with them.' ${ }^{15}$

So, what was the impact of European integration on Baltic ENGOs agendas? After the 2004 EU-accession, Baltic environmental groups had redefined the scope of their activities from wide-ranging tasks associated with sustainable development to those being more in line with the agenda of the INGOs and currently, the majority of ENGOs are strongly affiliated with INGOs. Since accession, WWF Latvia has been actively advising in the development of environmental policy by propagating alternative rural development scenarios. In a word of its members, 'WWF has been very supportive in conservation of endangered species and habitats. It went as far as to encourage us [i.e. its Baltic partners, EWF and WWF Latvia] to secure financial incentives for participation [of other residents] from local business and officials. ${ }^{16}$ When, in the course of several years following the EU-accession international financial support for the ENGOs dried out, the number of the ENGOs in the region fell dramatically down to a dozen in Lithuania, with slightly more in Latvia and approximately a hundred in Estonia. ${ }^{17}$ The question remains, of course, whether the change in environmental engagement across the region is indicative of trends imported by the INGOs during the period of close cooperation or was a result of domestic view on the human place in the environment.

Since 2004 Baltic environmental groups came increasingly to be associated with the observing activities of the INGOs in order to support state programmes for economic development rather than environmental protection. These governments' priorities were at odds with any concept that the Baltic ENGOs had been exposed to in their contacts with the INGOs: neither strong, nor weak sustainability could take place under the circumstances when competition for economic resources was dominant. And the Baltic authorities engaged ENGOs to legitimise the shift in attention from environmental issues towards increasing competitiveness of national economies by bringing in project grants and infrastructural

14 Interview, Lithuanian Fund for Nature (Vilnius, August 2009).

15 Interview, Green Freedom (Riga, August 2009).

16 Interview, Estonian Wildlife Fund (Tartu, July 2009).

17 Report on the meeting of the Baltic ENGOs, Jurmala November 15-16, 2006. 
investment. The international links of the Baltic ENGOs were welcome by the local policymakers and users, but cooperation sat uneasily with domestic publics.

This tension reflected the moods of environmental activists across the EU, increasingly critical of decisions over domestic environments made by the global economic actors and European policymakers while universally paying lip service to the UNECE Convention on Access to Information, Public Participation in Decision-making and Access to Justice in Environmental Matters is equally visible throughout the Eastern Baltic region. Some local environmental groups referred to nature as a resource for nation-building, while activists embedded in international networks focused upon the environment to enhance economic development. Although some foreign funding was taken up by all of the ENGOs in one form or another, these groups were not normally part of environmental policymaking process. Both these developments have supported domestic perceptions of nature as a national resource, receiving additional support in the course of European enlargement when environmental activism literally 'paid off'.

As observed above, cooperation of the Baltic ENGOs with the INGOs and grant givers in the run-up to EU-accession had many positive effects on their engagement with environmental policies. At the same time, however, there were changes that made cooperation between the environmental activists more difficult. Despite the range of activities, the mainline environment activities among the ENGO groups in the Baltic region remained remarkably consistent. While at first the Baltic ENGOs shifted away from conservationism to goals of ecological sustainability to mitigate risks, EU-accession made most groups capitalize on opportunities related to environmental investment. ${ }^{18}$ On the one hand, Baltic ENGOs continue to promote environmental awareness, by tabling ecological issues for discussions in a range of ministries in their states and thus increasingly cooperating with the policymakers, favouring economic interests and presenting environmental issues as an opportunity for business. On the other hand, international interference in identifying issues of concern appeared for many ENGOs to provide only a short term solution because it was strongly linked to financial input from the INGOs, Western donor institutions and governments. ${ }^{19}$ In both positions, environment features as a reference point for national identity as well as an economic resource.

The example of Baltic ENGOs suggests that this process is tightly knit with opportunities to secure economic opportunities linked to but were not explicitly about environmental resources. As observed above, aligning local actions with the rhetoric of European donor organisations on ecological modernization was essential for the survival of many ENGOs before the 2004. In the pre-accession phase, the Baltic ENGOs increasingly identified with the goals and means of the INGOs because these ensured financial support for activities on the ground. After the EU-accession international funding became scant and financial pressures sharply increased after 2008 financial downturn, making many ENGOs dispose with comprehensive environmental monitoring and return to programmes advocating their stewardship over nature.

18 Interviews, Estonian Society for Nature Conservation (Tallinn, July 2009), Green Freedom (Riga, August 2009), Lithuanian Fund for Nature (Vilnius, August 2009).

19 Interview, Lithuanian Green Movement (Vilnius, July 2009). 


\section{Making sense of bottom-up view of development: The case of Latvia}

The nature of the EU's engagement with the NGOs over the 'short decade of enlargement' reflected a functional understanding of what civil society can do. Limiting the remit of state dialogue with civil society actors to the latter instrumental engagement in supervising policy implementation yet not negotiating regulations, developed a domestic consultancy-oriented professional sector, focussing on management and conflict resolution rather than on contestation (Carmin, 2010). At the time of EU enlargement, promotion of NGO activities was high on priority list of Western donor organisation because it was linked to consolidation of the rule of law in accession states and establish liberal democracy as the only game in town. Prior to EU accession, NGOs could alert the EU of serious implementation problems and organise public campaigns at the domestic level, making governments more exposed and more vulnerable to watchdog activities of civil society (Börzel and Buzogány, 2011; Sudbery, 2010). After the accession however international funds ran dry and monitors struggled to maintain public interest in issues of relevance for wider society. As the more qualified personnel moved into private sector, the remaining activists were faced with an increasing difficulty to apply for EU funding and participate in European networks unless they already had past experience to rely on.

The peculiar form that Latvian environmental groups have assumed therefore is highly illustrative of bottom-up initiatives witnessed elsewhere by the civil society initiatives that positioned themselves in an opposition to state sponsored goals of economic development agenda. Latvian environmentalists have been able to mobilise on the tide of public scepticism about the ability of the state to deliver economic prosperity and have effectively tapped the combination of real and imagined concerns about the implications of this country's integration into the 'club of wealthy nations'. As a result, some ENGO activists embrace the view of national ownership of the environment, returning to a local 'vision of nature as a place where the [ethno-] nation is at home and can do how it pleases. ${ }^{20}$ If nothing else, the return of nativist concepts into environmental agendas always remained a possibility for both the locally focused ENGOs and those exposed to INGOs agendas alike but was forestalled by the influx of international funding.

When the global financial turmoil hit Latvia in 2008 its government had to request international bailout. As a result since February 2009 most of the spending in the public sector and projects aimed at the development of the environmental sustainability agenda was either scaled down, or was permanently withdrawn. This had an immediate impact on consolidation of grassroots groups that from the time on could be effective only if they cooperated with the state and thus had access to scarce public funding. Since 2009, many of the largest partners in state sponsored activities albeit de facto enjoying an NGO status were heavily reliant on state financial support to provide expertise that informed the and resulted in policies promulgated by the Latvian state. During the time, many INGOs that were originally created to promote citizen participation became increasingly professionalised to mirror state agendas. While considerable attention in the Latvian context has been paid to the positive 
impact NGOs have had on refocussing state priorities, we witness a much more subtle cooptation of civic groups into the policy domain.

Since the conditions of economy have deteriorated, Latvians increasingly turned to consumer-led initiatives favouring environmental produce and resulting in the consumeroriented environmental development. Since 2009 there has been a perceptible growth of groups promoting ideas that were previously only associated with a segment of society positioning itself as 'living off the nature'. At first multiple direct buying groups, the socalled 'box schemes' (tiešās pirkšanas grupas) emerge in the capital Riga, spreading into metropolitan area towns of Sigulda and Ogre, finally reaching into predominantly rural urbanities such as Gulbene and Cesis. These newly emerging links between farmers and urban residents are particularly surprising given the strong existing link of city dwellers regularly receiving extensive amounts of foodstuffs from their relatives residing in rural areas. These 'box schemes' particularly are have established mutual support and information exchange systems during strengthening their position vis-à-vis supermarket chains throughout the country.

Offering employment opportunities in conditions when labour market was contracting allowed many of the former ENGO members to promote environmental development goals via projects emphasising collective responsibility and involvement in environmentally aware work. Thus the landscape of the NGOs promoting environmental goals has increased from a relatively small pool of globally embedded NGOs with an accumulated operational capacity thanks to their long-term presence in Latvia, such as Friends of the Earth (Zemes draugi). However, many formerly active members of the ENGOs move away from their exclusive commitment to environmental concerns to dedicate time and energy to salaried work across the country on an array of issues. While the government has delegated development of environmental solutions to economic actors and promoted technical solutions to ecological change, it implicitly also affirmed the discourse of 'living off the nature'. Many groups were 'back to fostering traditional national lifestyles and environmentally sensitive behaviour, all this supports political rhetoric of national environmental concerns but does not help environment. ${ }^{21}$

Former ENGO activists have also been pivotal in establishing private schools such as Ikšksiles Brīvā skola and a network of eco-schools, (Ekoskolas) both promoting and consolidating ideals of Latvian nation's close ties with the nature. A part of this national return to nature is witnessed by the growing popularity of the 'Lielā talka' since 2009, the traditional springtime cleaning of cities and the country side across the country. On the one hand, one could surmise that the growing awareness of economic vulnerability by large segments of society have assisted the 'return to the tradition' across the range of social strata and were facilitated by the age-old image of the nature as the 'resource of the nation'. On the other hand, our discussions with the highly educated professional leaders of both the environmental and social groups reveal that the ultimate push for their focus on the 'nature' has been caused by the dearth of economic opportunities during the time. Many of the former members of ENGOs have honed their skills by organising fellow citizens for a shared environmental, and just as well economic cause creating opportunities for occupation and

21 Interview, Latvian Green Movement (Riga, August 2015). 
employment. The boom of small enterprises supplying ecological and artisan products is illustrative of the trend, with newly emerging ecological products such as Liberta berrzu sulas offering birch-sap wine and champagne, urban apiary Baltu Drava and one of the uppermarket Mádara Ecocosmetics have all started as small home-based producers with a limited market experience but a strong network of potential consumers from the ENGO activist networks to rely on. Since the 2010 these and other companies have successfully come to occupy not only a niche of ecologically aware consumers, but gradually are represented in supermarket chains appeasing also those consumers aware of environmental issues in the country, but also concerned with environmental impact on health.

The successful development of ecological products by the former environmental activists additionally draws attention to the impact of a better educated, more economically resourceful segment of society has had on changing practices of the general public in Latvia. This emerging consumption patterns all reflect the growing acceptance of environmental awareness as a result of the past ENGO activity. For example, Kalnciema Kvartāls, the first and only successful farmers' market in Riga has driven the interest of retail chains and introduction of home-made products to supermarkets across the country. This change required passing of additional legislation allowing home-made products to be delivered to big retailers, the amendments introduced to legislation by the retail lobby in the country.

Though some of the NGOs that have emerged since the 2009 foster links to global environmental networks such as Transition towns (Pärmainu iniciatīvas), there is a profusion of local groups operating on a much smaller scale and as a result highly dependent on volunteers and project funding from outside Latvia. As a result of scant financial capital, many of the NGOs frequently redefine their work focus and deliver expertise short-term but are largely unable to follow through with the issues they have identified in their reports. However, it should be noted that where NGOs are able to develop a set expertise and following up on their original ideas, their operational base is limited to a small group of volunteers clustered about a strong and determined leader. For example, the Homoecos a longstanding and successful ENGO has maintained a close circle of activists delivering numerous activities on issues as diverse as sustainable development, climate change, food waste, impact of packaging, while relying on a steady inflow of international volunteers supporting the work. Due to constant need to apply for and manage external funding many of the Homoecos' activities lack a sense of continuity, moving from one issue to another and working alternately on topics of immediate public concern.

It is in part these small and locally operating groups that put pressure to bear on the local authorities to deal with the legacies of environmental degradation and face up the emerging challenges. Some of the most visible cases concerns pollution of water reserved in the country. One of the most widely publicised issues in 2015 involved local activists who attracted media interest and by doing so forced state authorities to investigate the cases of fish dying in Slokenbeka Lake of the peripheral municipality of Tukums. While several similar cases of Ica river contamination (2013), water pollution in Katvaru parish (2014) have not solicited any governmental response, in 2015 the State Environmental Service (SES) has issued an opinion of the local manufacturers' adverse impact on the quality of water in the area. These and similar cases caused by agricultural and industrial waste and insufficient waste management have been raised by the concerned ENGO activists throughout the 
country. The most effective of these includes the resolution of the legacies of environmental degradation in relation to what is known as 'tar ponds' (Gudronu dīki). The SES has sought and received the EU funding to clear the pollution in the ponds in 2015, but is currently locked in dispute with the private enterprise earmarked to perform the cleaning, causing considerable consternation of local and national ENGO activists.

Indeed, Latvian state has repeatedly claimed lack of personnel and financial resources to monitor activities related to environmental protection particularly in the light of competing interests of environmental groups and the strong business lobby. While at the time, weak state institutions allow ENGOs to attract international, mainly EU funding to develop monitoring schemes and non-governmental institutions competing with municipal organisation of waste management and later extract profits. The availability of grants to develop green energy projects, particularly wind-farms has been susceptible to such exploitation and is rumoured for being particularly prone to abuse by the officials tasked with controlling environmental regulations for their personal gain.

One of the wider known examples of such a collusion of state and NGO interests is the establishment of the national quality scheme 'Green spoon' (Zaļā karotīte) in 2001. Originally the label was to facilitate consumers' choice of produce from Latvia in anticipation of the EU required ban on country-specific designation of products' origins. IN the years before the EU accession, the Latvian state invested heavily in the campaign to boost consumers' recognition of the scheme, yet the growing recognition of the label allowed food producers' professional organisations to apply the label as an indicator of products origins rather than as an indicator of quality. First and foremost, whilst the government lost its definitive role as an 'owner' of the label, unable to criticise the flaws in the scheme's original design and mechanisms of brand allocation. More worryingly however, while the label has drawn consumers to local goods, it gradually side-lined the products manufactured using biological standards. The problem is most visible in the way how EU Green Public Procurement (GPP, Zalais publiskais iepirkums) suggestions were being implemented in national context (Cabinet of Ministers, 2014). GPP is one of the instruments that state can deploy to support more sustainable modes of production. Within the context of economic competition for market shares, local products such as those marked with the 'Green spoon', and biologically produced goods were perceived as equal and promoted as such by the environmental groups despite products' different ecological impact. Thus, state has offered a support instrument for local products and local enterprises while reducing the competitiveness, presence and importance of biological products in reaction to both the pressure from producers as well as to environmental groups, aggrieving the bio-farming community and their supporters.

Overall however, the operations of many ENGO initiatives, whether local or globally embedded, regardless of the sources for their work and length of activism in the country tend to be small and changes they make - slow. Regardless, some significant projects have been initiated by the NGOs since 2009 and have de facto been a result of several groups' separate initiatives delivered under a joint umbrella. The introduction of the genetically modified crops has caused mobilisation across the civil society community to attained shred environmental outcomes. This resulted in application of anti-GMO regulations across the country, with local ENGO activists lobbying municipalities to regulate the introduction of 
genetically modified crops into the countryside. Notably, the national Friends of the Earth has been pivotal in this endeavour, and was building upon the successful cooperation between local community activists across the country during the so-called 'Seed riot' (Sêklu dumpis) in 2012. This mobilisation of environmental activists was targeting the small farmers traditionally growing autochthonous plants, as well as state authorities aiming to certify all species sewn across the country. The conflict resulted with small farmers securing their rights to grow and exchange their seeds and thus introducing greater variety of grown plants, resulting in the introduction of neophytes into ecosystems for economic, rather than environmental reasons. Both cases illustrate development of environmental lobby in the nongovernmental sector despite the fierce competition for project funding, lack of joint environmental agendas and coordination in lobbying.

The two competing positions on environment as a reference point for national identity and as an economic resource closely reflect the structural conditions within which environmental activists operate across the postcommunist region more generally. Whatever the impact of European integration and the imports of the INGOs, impact of the economic crisis in the Baltic region made local environmental activists concentrate on issues which they could market to national publics as economic opportunities. Though regularly presenting a common front with the public and against the government agendas, Latvian environmentalists have regularly appealed to population but mobilisation that has proven most successful, was more often than not initiated by political or by the economic actors.

\section{Conclusion}

The paper investigated the reach of a general theory that civil society groups reflect prevalent expectations of society in which they operate. Because the members of multiple social groups interact in NGO forums, they are said to support citizen-led practices through cooperation on cross-cutting issues making representation of diverse interest possible. This paper has reported a test of the hypothesis that environmental civil society groups face a dilemma of negotiating between the general and particularistic goals with regard to development goals under the conditions of economic transition.

The past research identified Baltic environmentalism as the one that establishes and reinforces the symbolic link between the natural environment and sovereignty over state resources. As we have demonstrates, the economic rationale has dominated ENGOs agendas throughout. Although Baltic environmental activists mobilised perspectives of nature as a cradle of their respective nations, they achieved success only when framing environment as an asset for economic development. The review of the ENGO activities in Estonia, Latvia and Lithuania supports this view, yet the dynamics observed are not unique to the Eastern Baltic. Since the collapse of communism, the CEE ENGOs have moved toward some form of sustainability following the 'downloading' of European policies into domestic agendas. Specifically, in the pre-enlargement phase an increasing access to Western European knowhow meant switching rhetoric from conservation to eco-efficiency. However after the EUaccession financial support for the Western donor organizations decreased, so did ENGOs readiness to engage in projects that were not bringing financial revenues. 
As this paper demonstrated, seeing 'nature' as a particularistic resource of ENGOs left little opportunity for cooperation between environmental groups outside the issues of economic development, largely because both ecological modernisation and sustainable development agendas promised high returns which the established ENGOs earmarked for themselves. Lithuanian ENGOs were slow to cooperate with the Ministry for the Environment and cooperate even less with each other. Latvian ENGOs began with a government sponsored Council, yet still basically only approve policymakers' decisions. Only in Estonia does one see communication between ENGOs and state institutions, but such cooperation, as one activist interviewed made clear is, 'bought with the money of foreign grants.' 22 The impact of the economic downturn has further reshaped the ENGOs agendas again: they became less likely to act upon environmental issues if they see it as being a constraint on economic opportunities of their individual members.

The analysis presented supports the argument that the NGOs tap into a range of resources to maintain their role as partners of policymakers and to maintain momentum in public debates. Probably the most telling effect of collusion between political and economic agendas at the 'green side' of the political spectrum in the Baltic States is testified by the recent election of Raimonds Vejjonis, the member of the only viable Baltic Green Party to the post of Latvia's President in 2015. Vèjonis held ministerial posts with portfolio for environmental protection in different departments between 2002 and 2011, precisely at the time when the countries ENGO landscape has experienced consolidation around the nexus of environmentally sustainable economic development. It is during this period of time that Latvian ENGOs have established and maintained their gatekeeping position as facilitators of their members' access to economic opportunities. Toeing the rhetoric that brought economic benefits to ENGOs, their members and communities, literally paid the bills of all parties involved only reinforcing domestic perceptions of nature as a national economic resource.

In the Baltic context, only the NGOs translating their objectives as and securing their position of guardians of economic resources in particularistic terms, such as relating to the natural environment, persevere and maintain their status as partners of policymakers and legitimate interlocutors of largely politically alienated public. What is more however, we have also illustrated that environmental protection is not one of the state priorities, even if environmentally sustainable development is high on the political agenda. Despite the fact that officially Latvia's long-term development plan signposts the need to balance economic development with environment and public welfare needs, both the state and the ENGOs tap popular, if not outright populist perceptions of the nature as Latvian nation's resource to their own benefit at cost of commitment to environmentally sustainable development. As this paper argued, specifically Latvian and more generally Baltic ENGOs exposed to agenda of sustainable development and provided with skills for comprehensive environmental management had received stark financial incentives to persevere. These two imports only ushered the ENGOs to chase the green buck and highlighted perceptions of the 'nature' as Baltic nations' economic resource.

22 Interview, Estonian Green Movement (Tartu, April 2009). 


\section{References}

Agarin, T., 2011. Civil society versus nationalizing state? Advocacy of minority rights in the post-socialist Baltic states. Nationalities Papers 39, 181-203.

Agarin, T., 2009. Where have all the Environmentalists Gone? Baltic Greens in the mid1990s. Journal of Baltic Studies 40, 285 - 305.

Almond, G.A., Verba, S., 1963. The Civic Culture. Political Attitudes and Democracy in Five Nations. Princeton University Press, Princeton, NJ.

Auer, M.R., 1998. Environmentalism and Estonia's independence movement. Nationalities Papers 26, 659-676.

Baker, S., Jehlicka, P., 1998. Dilemmas of transition: The environment, democracy and economic reform in East Central Europe [Special issue]. Environmental Politics 7, 126.

Baker, S., Welsh, I., 2000. Differentiating western influences on transition societies in eastern Europe: a preliminary exploration. Journal of European Area Studies 8, 79-103.

Bērziņš, J., 2000. Latvija 19. gadsimtā: vēstures apceres. Latvijas Vēstures Institūta apgāds.

Bomberg, E., 2007. Policy learning in an enlarged European Union: environmental NGOs and new policy instruments. Journal of European Public Policy 14, 248-268.

Börzel, T., Buzogány, A., 2011. Environmental organisations and the Europeanisation of public policy in Central and Eastern Europe: the case of biodiversity governance. Environmental Politics 19, 708-735. doi:10.1080/09644016.2010.508302

Busmanis, P., 1991. Country Report on the present environmental situation in agricultureLatvia.

Cabinet of Ministers, L., 2014. Noteikumi par vides kritēriju piemērošanu un piedāvājuma izvēles kritēriju noteikšanu pārtikas produktu piegādes un ēdināšanas pakalpojumu iepirkumiem. Ministru kabineta noteikumi Nr.673.

Caddy, J., 2000. Implementation of EU environmental policy in Central European applicant states: the case of EIA, in: Knill, C., Lenschow, A. (Eds.), Implementing EU Environmental Policy. New Directions and Old Problems. Manchester University Press, Manchester, pp. 197-221.

Carmin, J., 2010. NGO capacity and environmental governance in Central and Eastern Europe. Acta Politica 45, 183-202.

Carmin, J., Vandeveer, S., 2004. Enlarging EU environments: Central and Eastern Europe from transition to accession. Environmental Politics 13, 3-24.

Chandhoke, N., 2001. The civil and the political in civil society. Democratization 8, 1-24.

Crotty, J., 2006. Reshaping the Hourglass? The Environmental Movement and Civil Society Development in the Russian Federation. Organization Studies 27, 1319-1338.

Dawson, J.I., 1996. Eco-Nationalism: Anti-Nuclear Activism and National Identity in Russia, Lithuania, and Ukraine. Duke University Press, London.

Diamond, L., Plattner, M.F., Chu, Y., Tien, H., 1997. Consolidating the Third Wave Democracies. Themes and Perspectives. John Hopkins University Press, London.

Eckerberg, K., 1997. Comparing the local use of environmental policy instruments in Nordic and Baltic countries-the issue of diffuse water pollution. Environmental Politics 6, $24-47$.

Ehrlich, Ü., Krusberg, P., Habicht, K., 2002. Land cover types and ecological conditions of the Estonian coast. Journal of Coastal Conservation 8, 109-117.

Fagan, A., 2005. Taking stock of civil-society development in post-communist Europe: Evidence from the Czech Republic. Democratization 12, 528-547. 
Fagan, A., Sircar, I., 2011. Environmental politics in the Western Balkans: river basin management and non-governmental organisation (NGO) activity in Herzegovina. Environmental Politics 19, 808-830.

Galbreath, D.J., 2009. Introduction: From Phosphate Springs to “Nordstream”: Contemporary Environmentalism in the Baltic States. Journal of Baltic Studies 40, 279 - 284.

Gille, Z., 2000. Transitional economies -- Legacy of waste or wasted legacy? The end of industrial ecology in post-socialist Hungary. Environmental Politics 9, 203 - 231.

Gooch, G.D., 1995. Environmental beliefs and attitudes in Sweden and the Baltic states. Environment and Behavior 27, 513.

Gorton, M., Lowe, P., Zellei, A., 2005. Pre-accession Europeanisation: The Strategic Realignment of the Environmental Policy Systems of Lithuania, Poland and Slovakia towards Agricultural Pollution in Preparation for EU Membership. Sociologia Ruralis 45, 202-223.

Grīnberga, L., 1999. Latvijas lauksaimniecības biedrības un to apbalvojumi 19. gs. beigās20. gs. sākumā. Latvijas Arhīvi.

Grivins, M., Tisenkopfs, T., 2015. A discursive analysis of oppositional interpretations of the agro-food system: A case study of Latvia. Journal of Rural Studies 39, 111-121.

Grosse, T.G., 2010. Social dialogue during enlargement: The case of Poland and Estonia. Acta Politica 45, 112-135.

Henderson, S.L., 2002. Selling Civil Society: Western Aid and the Nongovernmental Organization Sector in Russia. Comparative Political Studies 35, 139.

Hicks, B., 2004. Setting Agendas and Shaping Activism; EU Influence on Central and Eastern European Environmental Movements. Environmental Politics 13, 216-233.

Jacoby, W., 1999. Priest and Penitent: The European Union as a Force in the Domestic Politics of Eastern Europe. Eastern European Constitutional Review 8, 62.

Kaasik, T., Kallaste, T., Pallo, T., 1995. Programme of Sustainable Development of IdaVirumaa. A Report.

Kramer, J.M., 1983. The Environmental Crisis in Eastern Europe: The Price for Progress. Slavic Review 204-220.

Kratovits, A., 2001. The role of international regimes in the formation and maintenance of Baltic environmental cooperation. Journal of Baltic Studies 32, 289 - 307.

Kutter, A., Trappmann, V., 2010. Civil society in Central and Eastern Europe: The ambivalent legacy of accession. Acta politica 45, 41-69.

Lazdinis, M., Carver, A., Carlsson, L., Tõnisson, K., Vilkriste, L., 2004. Forest policy networks in changing political systems: Case study of the Baltic states. Journal of Baltic Studies 35, 402-419.

Lee, A.R., Norris, J.A., 2000. Attitudes toward environmental issues in East Europe. International journal of public opinion research 12, 372.

Linz, J.J., Stepan, A., 1996. Problems of Democratic Transition and Consolidation: Southern Europe, South America, and Post-Communist Europe. Johns Hopkins, Baltimore.

Locmele, K., 2014. Lauku diskurss presē latviešu valodā Latvijā (1989-2012).

LVA, 1996. National Environmental Policy Plan for Latvia. A Report [WWW Document].

McCauley, D., 2007. Environmental Mobilization and Resource-Opportunity Usage: The Examples of WWF-France, FNE and LPO in Policy Processes. French Politics 5, 333-353.

Meyer, D.S., 2004. Protest and political opportunities. Annual review of sociology 125-145.

Mirovitskaya, N., 1998. The Environmental Movement in the Former Soviet Union, in: Tickle, A., Welsh, I. (Eds.), Environment and Society in Eastern Europe. Longman, Harlow, pp. 30-66. 
Muiznieks, N.R., 1995. The Influence of the Baltic Popular Movements on the Process of Soviet Disintegration. Europe-Asia Studies 47, 3-25.

Mzavanadze, N., 2009. Sustainable Development in Lithuania: Between The Government Agenda and the Undiscovered Civil Society. Journal of Baltic Studies 40, 397 - 414.

Obradovic, D., Pleines, H., 2007. The capacity of Central and East European Interest Groups to participate in EU governance. ibidem-Verlag, Stuttgart.

Orr, S.D., 2011. Ethnic Identity and Civil Society in Latvia, Poland and Ukraine: The Case of Environmental NGOs.

Orr, S.D., 2008. Identity and Civil Society in Latvia, Poland, and Ukraine: Women's NGOs. East European Politics and Societies 22, 856-878.

Parau, C.E., 2009. Impaling Dracula: how EU accession empowered civil society in Romania. West European Politics 32, 119-141.

Pavasars, I., 2014. Environmentalism in Latvia: Two Realities. Journal of Baltic Studies 45, 39-55. doi:10.1080/01629778.2013.836829

Pavlínek, P., Pickles, J., 2005. Environmental pasts/environmental futures in post-socialist Europe, in: EU Enlargement and the Environment. Institutional Change and Environmental Policy in Central and Eastern Europe. pp. 237-265.

Pieper, K., 2006. Regionalpolitik während des EU-Beitrittsprozesses: Europäisierungseffekte auf regionale Akteure in Ungarn und Polen, in: Kutter, A., Trappmann, V. (Eds.), Das Erbe Des Beitritts. Europäisierung in Mittel-Und Osteuropa. Baden-Baden, Nomos. Nomos, Baden-Baden, pp. 295-316.

Pleines, H., 2011. Weakness as precondition of smooth integration? Representation strategies of functional interest groups from new member states at the EU level. Journal of European Integration 33, 507-521.

Reisinger, W.M., Miller, A.H., Hesli, V.L., 1995. Public behavior and political change in post-Soviet states. The Journal of Politics 57, 941-970.

Rootes, C., 2002. Global visions: Global civil society and the lessons of European environmentalism. Voluntas: International Journal of Voluntary and Nonprofit Organizations 13, 411-429.

Schwartz, K.Z.S., 2006. "Masters in Our Native Place": The politics of Latvian national parks on the road from Communism to "Europe.” Political Geography 25, 42-71.

Schwartz, K.Z.S., 2006. Nature and National Identity After Communism: Globalizing the Ethnoscape. University of Pittsburgh Press, Pittsburgh.

Sikk, A., Andersen, R.H., 2009. Without a Tinge of Red: The Fall and Rise of Estonian Greens. Journal of Baltic Studies 40, 349 - 373.

Slocock, B., 1996. The paradoxes of environmental policy in Eastern Europe: The dynamics of policy-making in the Czech republic. Environmental Politics 5, 501-521.

Sudbery, I., 2010. The European Union as political resource: NGOs as change agents? Acta Politica 45, 136-157.

Šūmane, S., 2010. Lauku inovācija: jaunu attīstības prakšu veidošana. Biologískās lauksaimniecības piemērs.

Tesnova, I., 1995. Latvia. An environmental report.

Tickle, A., Welsh, I., 1998. Environment and Society in Eastern Europe. Longman, Harlow.

Toomik, A., Liblik, V., 1998. Oil shale mining and processing impact on landscapes in northeast Estonia. Landscape and Urban Planning 41, 285-292.

Trenz, H.-J., Eder, K., 2004. The democratizing dynamics of a European public sphere. European Journal of Social Theory 7, 5-25.

Vogler, J., 1999. The European Union as an actor in international environmental politics. Environmental Politics 8, 24-48. 
Wallace, C., Pichler, F., Haerpfer, C., 2012. Changing Patterns of Civil Society in Europe and America 1995-2005. East European Politics \& Societies 26, 3-19.

Waller, M., Millard, F., 1992. Environmental politics in eastern Europe. Environmental Politics 1, 159-185.

Zakaria, P., 2013. Is corruption an enemy of civil society? The case of Central and Eastern Europe. International Political Science Review 34, 351-371. doi:10.1177/0192512112466880

Ziegler, C.E., 1992. Political Participation, Nationalism and Environmental Politics in the USSR, in: Massey, J.M. (Ed.), The Soviet Environment: Problems, Policies and Politics. Cambridge University Press, Cambridge, pp. 24-39. 